\title{
Developmental Mechanism of Limb Field Specification along the Anterior-Posterior Axis during Vertebrate Evolution
}

\author{
Mikiko Tanaka \\ Graduate School of Bioscience and Biotechnology, Tokyo Institute of Technology, B-17, 4259 Nagatsuta-cho, \\ Midori-ku, Yokohama 226-8501, Japan; mitanaka@bio.titech.ac.jp; Tel.: +81-45-924-5722 \\ Academic Editors: Vincenzo Zappavigna and Simon J. Conway \\ Received: 1 April 2016; Accepted: 17 May 2016; Published: 19 May 2016
}

\begin{abstract}
In gnathostomes, limb buds arise from the lateral plate mesoderm at discrete positions along the body axis. Specification of these limb-forming fields can be subdivided into several steps. The lateral plate mesoderm is regionalized into the anterior lateral plate mesoderm (ALPM; cardiac mesoderm) and the posterior lateral plate mesoderm (PLPM). Subsequently, Hox genes appear in a nested fashion in the PLPM and provide positional information along the body axis. The lateral plate mesoderm then splits into the somatic and splanchnic layers. In the somatic layer of the PLPM, the expression of limb initiation genes appears in the limb-forming region, leading to limb bud initiation. Furthermore, past and current work in limbless amphioxus and lampreys suggests that evolutionary changes in developmental programs occurred during the acquisition of paired fins during vertebrate evolution. This review presents these recent advances and discusses the mechanisms of limb field specification during development and evolution, with a focus on the role of Hox genes in this process.
\end{abstract}

Keywords: Hox; retinoic acid; Tbx4; Tbx5; limb field specification; evolution

\section{Introduction}

Paleontological evidence suggests that acquisition of the first pairs of fin-like structures occurred in the lineage of ancestral agnathans (jawless vertebrates; Figure 1a) [1,2]. The cephalochordate amphioxus and the agnathan lampreys are thought to have diverged prior to the acquisition of paired fins (Figure 1a) [3], and thus these animals could be good models for developmental comparisons to gain insights into the evolutionary sequence that lead to the acquisition of the limb-forming fields in the lateral plate mesoderm.

In gnathostomes (jawed vertebrates), limb buds appear as small bulges protruding from the body trunk at a specific position along the body axis during the development of gnathostome embryos. Specification of limb fields, which is tightly correlated with the initiation of limb bud formation, involves multiple steps [4]. The lateral plate mesoderm is regionalized into the anterior lateral plate mesoderm (ALPM; cardiac mesoderm) and the posterior lateral plate mesoderm (PLPM), which includes the presumptive limb-forming fields [5,6]. Retinoic acid signaling seems to play pivotal roles in this process $[5,6]$. In the PLPM, Hox genes are expressed in a nested fashion along the anterior-posterior axis and appear to be involved in the regionalization of the PLPM into forelimb, interlimb flank and hindlimb fields $[7,8]$. Then, the lateral plate mesoderm thickens and splits into the somatic and splanchnic layers sequentially from the anterior to posterior region of the embryos (Figure 1b) [9]. Subsequently, expression of limb initiation genes appears in the presumptive limb-forming fields [10]. Initiation of limb buds needs to occur at a precise position along the body axis, although little has been known until recently about the molecular mechanism linking limb positioning and initiation. Analyses of chick and mouse embryos, however, revealed that the Hox proteins that define the axial position of 
the limb-forming fields directly activate the transcription of the forelimb initiation gene, $T b x 5[11,12]$. Furthermore, developmental analyses of limbless amphioxus and lampreys have provided evidence for the sequential events that occurred during the acquisition of limb-forming fields in the body of vertebrates during evolution [4]. This review highlights these recent advances and discusses the mechanisms of limb field specification during development and during vertebrate evolution, with a special focus on the function of Hox genes.
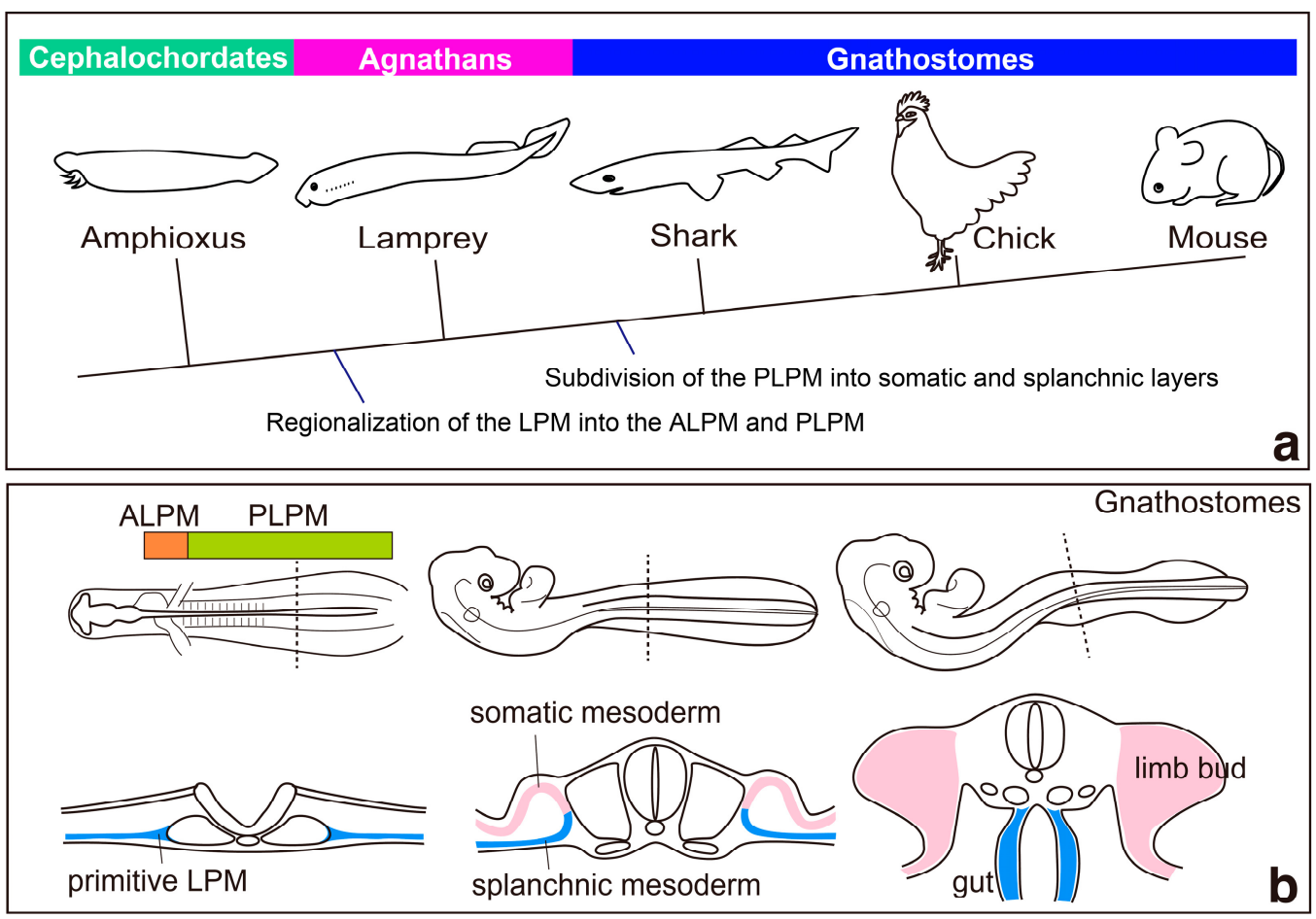

Figure 1. Model for the evolution of the lateral plate mesoderm (LPM); (a) a phylogenetic tree indicating the probable timing of the regionalization and subdivision of the LPM. See text for details. Modified after [4]. (b) development of the LPM in chick embryos. Bottom panels show schematic cross-sections at the wing level. The LPM is regionalized into the anterior lateral plate mesoderm (ALPM) and the posterior lateral plate mesoderm (PLPM). Then, the developing LPM splits into somatic and splanchnic mesoderm. Subsequently, somatic mesodermal cells proliferate and form limb buds, whereas splanchnic mesodermal cells contribute to gut formation. Modified after [9].

\section{Regionalization of the Lateral Plate Mesoderm into the ALPM and the PLPM: Retinoic Acid and Hox Genes}

During the development of gnathostome embryos, the lateral plate mesoderm is regionalized into the ALPM and the PLPM, including the presumptive limb-forming fields [5,6]. Recent developmental studies on zebrafish and mouse embryos suggested that such a regionalization of the lateral plate mesoderm is necessary to provide an environment permissive for forelimb-forming fields and that retinoic acid signaling has pivotal roles in this process [5,6]. In zebrafish, mutants for retinaldehyde dehydrogenase 2 (raldh2) lack pectoral fin buds (forelimb buds) [13,14], and embryos treated with retinoic acid inhibitor show the posterior expansion of the heart field and fail to initiate formation of pectoral fin buds [5]. During this process, retinoic acid signaling induces the expression of hoxb5b within the forelimb fields [5]. As hoxb5b restricts the number of atrial cells, it also restricts the posterior extension of the heart field to determine the anterior boundary of forelimb-forming fields, although its function is dispensable for forelimb formation [5]. Chick and mouse Hoxb5 orthologs have been implicated as direct targets of retinoic acid signaling [15-17]. Moreover, in mouse Hoxb5 mutants, the shoulder girdles shift their position, although morphological abnormalities of the heart have not been 
reported [18]. Thus, it is suggested that Hoxb5 mutants might have subtle cardiac defects, or be lethal, or other mouse Hox genes might have roles similar to those of zebrafish hoxb5b [5]. Multiple Hox genes are expressed in the heart fields of mouse and chick embryos $[19,20]$. However, heart phenotypes associated with the genetic inactivation of Hox genes have rarely been observed, which is probably due to the functional redundancy of paralogous Hox genes [21]. One notable exception is mouse Hoxa3 null mutants, which exhibit heart defects, including hypertrophy of the atria and the enlargement of the chief veins [22]. Heart phenotypes seen in Hoxa3 mutants, thus, have been implicated as a possible outcome of the expansion of the heart field [5].

Numerous studies on retinoic acid signaling in relation to the anterior-posterior patterning of the heart suggested roles for Hox genes in this process [21,23]. Treatment with retinoic acid enhances the expression of Hoxa4, Hoxd3 and Hoxb5 in chicken cardiogenic tissue [20]. In addition, Hoxb1, Hoxa1 and Hoxa3, downstream targets of retinoic acid signaling, define the distinct progenitor sub-domains of the secondary heart field in mouse embryos [24]. Furthermore, retinoic acid signaling is correlated with limb initiation and positioning in zebrafish, chick and mouse embryos $[5,6,25,26]$. Chick embryos treated with disulfiram, an inhibitor of retinoic acid synthesis, show hypoplasia, or a positional shift of the forelimb bud [25]. In mouse Raldh2 mutants, heart-forming fields expanded posteriorly, and forelimb initiation fails [6], as seen in zebrafish raldh2 mutants [5]. Thus, retinoic acid signaling seems to have a role in the regionalization of the lateral plate mesoderm into the ALPM and the PLPM [6,26,27]. In addition, in the pharyngeal endoderm and mesoderm of Raldh2 mouse mutants, Hoxa1 and Hoxb1 transcript levels are reduced [27], suggesting that the role of retinoic acid signaling in regionalizing the lateral plate mesoderm via regulation of Hox genes is conserved in mouse embryos.

An alternative model for the function of retinoic acid signaling in the regionalization process of the lateral plate mesoderm along the anterior-posterior axis has been proposed by Duester's group. They suggested that retinoic acid signaling delimits the cardiac and epiblast Fgf8-positive domains, and provides a permissive environment for the induction of forelimb (but not hindlimb) development [6]. Chromatin immunoprecipitation analysis revealed that all three retinoic acid receptor (RAR) isoforms indeed bind to the retinoic acid responsive elements near the $F g f 8$ promoter, suggesting that retinoic acid signaling directly represses $F g f 8$ expression [28]. Interestingly, transgenic zebrafish embryos expressing ectopic Fibroblast growth factor (Fgf) signaling show expansion of the heart field and failure of initiation of pectoral fin development [29]. These results seem to support the view that FGF signaling is involved in the regionalization of the lateral plate mesoderm and provides a permissive environment for forelimb induction [6].

During embryonic development, regionalization of the lateral plate mesoderm into the ALPM and the PLPM provides a permissive environment for forelimb induction. Therefore, regionalization of the lateral plate mesoderm might have been a crucial step for acquisition of the limb-forming field during the evolution of vertebrates. In vertebrates, the heart is located at the anterior end of the body trunk, whereas the primitive heart of amphioxus-consisting of peristaltic blood vessels-is located at the posterior-ventral part of the body [30]. Recently, the distribution of the ALPM and the PLPM has been examined in amphioxus embryos by using molecular markers (Figure 2) [4]. In amphioxus, AmphiHand, an ortholog of Hand1 and Hand2, which are expressed throughout the lateral plate mesoderm of zebrafish, chick and mouse embryos [31-33], is expressed throughout the ventral mesoderm (Figure 2) [4]. Interestingly, in amphioxus, both AmphiNkx2-tin and AmphiTbx20-orthologues of Nkx2.5 and Tbx20, which are expressed in the cardiac mesoderm [32,34-36]-are also expressed throughout the ventral mesoderm. These results suggest that the amphioxus ventral mesoderm is not molecularly regionalized into cardiac versus posterior ventral mesoderm (Figure 2) [4]. In the limbless agnathan lamprey, Lethenteron japonicum Tbx20 (LjTbx20) is expressed in the anterior part of the lateral plate mesoderm [37], whereas $L j M y b$, an orthologue of $c-m y b$ that is expressed in the PLPM, is expressed in mesodermal cells posterior to the LjTbx20-positive area (Figure 2) [4]. These results suggest that the lateral plate mesoderm of lamprey, a limbless agnathan, is regionalized into the ALPM and the PLPM as seen in gnathostomes (Figure 2) [4]. 


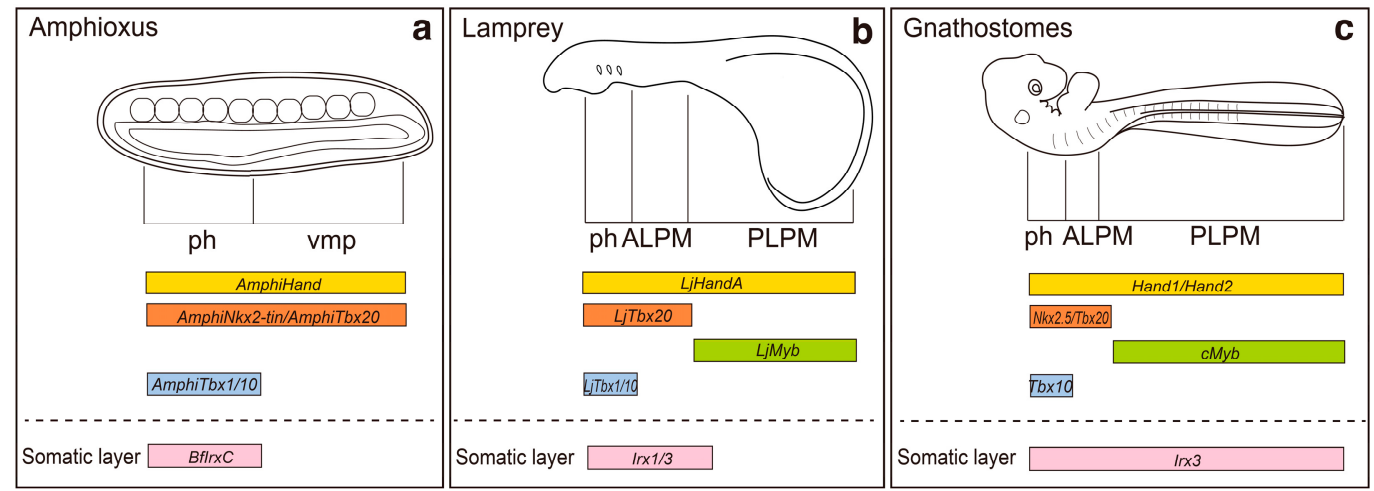

Figure 2. Schematic model for regionalization and differentiation of the ventral mesoderm and the lateral plate mesoderm (LPM) in (a) amphioxus, (b) lampreys and (c) gnathostomes. Yellow, orange, green and blue bars represent the distribution of molecular markers for the ventral mesoderm/LPM (AmphiHand, LjHandA, Hand1, Hand2), the pharyngeal mesoderm (ph) and ALPM (AmphiNkx2-tin, AmphiTbx20, LjTbx20, Nkx2.5, Tbx20), the PLPM (LjMyb, cMyb), and the pharyngeal mesoderm (AmphiTbx1/10, LjTbx1/10, Tbx10), respectively. Pink bars represent the distribution of Irx3 orthologs (BfIrxC, Irx1/3, Irx3), which are expressed in the somatic layers of the LPM. vmp, ventral mesoderm posterior to the pharynx. See text for gene expression references. Modified after $[4,38]$

In lampreys, expression of $\operatorname{Lj} T b x 1 / 10$, an ortholog of $T b x 1$ and $T b x 10$ that is a marker of pharyngeal mesoderm [39], is restricted to the pharyngeal mesoderm [40]. Importantly, expression of AmphiTbx1/10 is also restricted to the pharyngeal ventral mesoderm [41], suggesting that the ventral mesoderm of amphioxus is indeed regionalized into the pharyngeal ventral mesoderm and ventral mesoderm caudal to the pharynx (Figure 2) [4]. Therefore, it seems that the system to regionalize the ventral mesoderm along the anterior-posterior axis was already established in the cephalochordate lineage, although the ventral mesoderm was not yet separated into the cardiac and posterior ventral mesoderm [4].

Previous studies suggest that retinoic acid signaling is involved in the patterning of various organs along the anterior-posterior axis both in amphioxus and lampreys [42-47]. RARs have been identified in amphioxus [42] and lampreys [43]. Furthermore, treatments with excess retinoic acid or retinoic acid inhibitors affect the anterior-posterior patterning of amphioxus and lampreys [42-47]. Interestingly, lamprey embryos treated with retinoic acid fail to form a heart [47], supporting the view that retinoic acid has retained its importance for the regionalization of the lateral plate mesoderm into the ALPM and the PLPM during evolution (Figure 3) [4]. Therefore, it is likely that retinoic acid signaling and its roles in the anterior-posterior patterning were present in the common ancestor of vertebrates and amphioxus. However, a recent study on amphioxus embryos revealed that the function of retinoic acid signaling in anterior-posterior patterning of somites in amphioxus might not be the same as in vertebrates [48]. Bertrand et al. showed that retinoic acid signaling has critical roles in somitogenesis in amphioxus; however, it does not antagonize Fgf signaling. Therefore, the anterior-posterior patterning system controlled by mutual inhibition between retinoic acid and Fgfs during somitogenesis might have been acquired after the divergence of amphioxus and ancestral vertebrates [48]. Zhao et al. proposed that, during mouse embryogenesis, antagonism between retinoic acid and Fgf8 provides the permissive environment for the forelimb-forming field in the PLPM [6]. Thus, we should consider the possibility that alteration of the distribution of retinoic acid in the lateral plate mesoderm and/or acquisition of a novel antagonistic function of retinoic acids and Fgfs might have been critical for subdividing the lateral plate mesoderm into the ALPM and the PLPM during vertebrate evolution (Figure 3). 

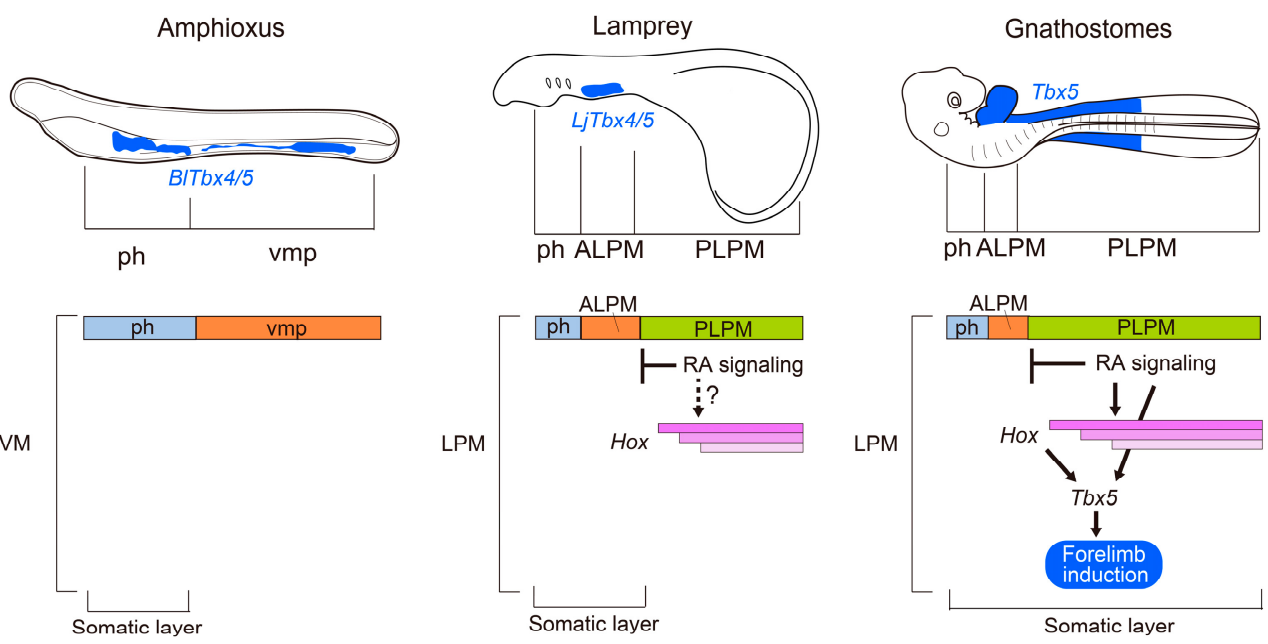

Figure 3. Schematic model for the acquisition of forelimb-forming fields during evolution. Light blue, orange and green bars represent the pharyngeal mesoderm (ph), ventral mesoderm posterior to the pharynx (vmp)/ALPM and PLPM, respectively (see Figure 2 for details). The ventral mesoderm (VM)/LPM is regionalized into the ALPM and PLPM in lampreys and gnathostomes, but not in amphioxus, and retinoic acid signaling seems to be involved in this process. Nested expression of Hox genes (pink bars) is observed in lampreys and gnathostomes, but not in amphioxus. Blue regions in the embryos are expression domains of Tbx5 orthologs $(B l T b x 4 / 5, L j T b x 4 / 5, T b x 5)$ in the VM/LPM. In amphioxus, BlTbx4/5 (blue) appears in both ph and vmp, similar to cardiac markers (AmphiNkx2.5-tin/AmphiTbx20; see Figure 2). In lampreys, LjTbx4/5 expression (blue) is expressed in the ALPM; it is not expressed in the unseparated PLPM. In gnathostomes, retinoic acid signaling, as well as Hox proteins, directly activates expression of $T b x 5$ (blue) in the somatic layer of the PLPM to induce forelimb formation $[11,49,50]$. See text for additional references and details.

In gnathostomes, several lines of evidence indicate that retinoic acid signaling regulates the transcription of Hox genes and leads to the regionalization of the lateral plate mesoderm along the anterior-posterior axis $[5,21,23,27]$. However, transcripts of Hox genes have not yet been observed in the segmented mesoderm (the progenitor of the ventral mesoderm) of amphioxus (Figure 3) [51,52]. In amphioxus, retinoic acid signaling regulates the expression of Hox genes in anterior-posterior patterning of the endoderm, central nervous system and ectoderm at the neurula stage $[45,53,54]$. In addition, retinoic acid signaling directly regulates expression of Hox genes to pattern the anterior-posterior axis during gastrulation [55], suggesting that the regulatory mechanism of Hox gene transcription by retinoic acid signaling has already been established in the common ancestors of amphioxus and ancestral vertebrates. As the nested expression of Hox genes has been observed in the PLPM of both lamprey and gnathostome embryos [4,7], the acquisition of the novel expression domain for Hox genes in the lateral plate mesoderm-possibly via alteration of distribution of retinoic acid and/or the acquisition of a novel function of retinoic acid signaling-seems to be required for the regionalization of the lateral plate mesoderm into the ALPM and the PLPM (Figure 3).

In lamprey embryos, Hox genes are indeed expressed in a nested fashion in the PLPM [4], although limb formation is not initiated in this region (Figure 3). In gnathostomes, subsequent to the regionalization of the lateral plate mesoderm into the ALPM and the PLPM, the lateral plate mesodermal cells proliferate and are subdivided into the somatic and splanchnic layers beginning from the anterior toward the posterior part of the body (Figure 1b) [9]. Limb buds then appear as protrusions of the somatic layers in the PLPM. In contrast, in lampreys, the lateral plate mesoderm is subdivided into the somatic and splanchnic layers in the ALPM, but not in the PLPM (Figure 2) [4]. Thus, it is possible that lampreys cannot form limb buds because the underdeveloped PLPM does not split into the somatic and splanchnic layers [4]. Until recently, subdivision of the PLPM had not been observed during embryogenesis of any teleost fishes. However, a recent histological analysis 
of pufferfish (Takifugu niphobles) embryos at a very early stage (eight-somite stage) revealed that the lateral plate mesoderm is indeed subdivided into somatic and splanchnic layers both in the ALPM and the PLPM [56]. Importantly, cells from the PLPM of lampreys contribute to the formation of peritoneal epithelium and blood cells, but not the body wall [4,57]. Therefore, it is likely that the proliferation and differentiation of the PLPM, as well as formation of the coelom cavity, might have been a crucial step in acquiring paired appendages during the evolution of vertebrates [4,57]. In gnathostomes, Forkhead box $F(F o x F)$ is expressed throughout the PLPM prior to the separation; subsequent to the subdivision, FoxF transcripts are restricted to the splanchnic mesoderm and Iroquis homeobox 3 (Irx3) expression appears in the somatic mesoderm [9]. In lampreys, LjIr $x 1 / 3$ is expressed in the somatic layers of the ALPM, but not in the PLPM, although LjFoxF is expressed throughout the PLPM [4] (Figure 2). Furthermore, in amphioxus, AmphiFoxF is expressed from the pharynx to the posterior end of the body trunk [4], and Branchiostoma floridae IrxC (BfIrxC) is expressed in the ventral mesoderm at the level of the pharynx, but not in the ventral mesoderm posterior to the pharynx (Figure 2) [58]. Therefore, it is likely that the common ancestor of amphioxus and ancestral vertebrates had the FoxF-positive lateral plate mesoderm, and Irx3-positive somatic mesoderm seems to have appeared at the cardiac level after the divergence of ancestral chordates and vertebrates. The FoxF-positive unseparated PLPM seems to have been acquired prior to the lamprey lineages. The Ir $x 3$-positive somatic layers seem to have appeared in the PLPM after the divergence of lampreys and vertebrates [4], and provided permissive environment needed for emergence of fin-forming fields during evolution.

\section{Specification of Limb-Forming Fields: $T b x 4, T b x 5$ and Hox Genes}

In gnathostomes, the lateral plate mesoderm is divided into the ALPM and the PLPM, and Hox genes seem to be involved in this process [5]. Although regionalization of the PLPM along the anterior-posterior axis by Hox genes has not been studied as extensively as in the nervous system or in somites, it has been proposed that expression patterns of Hox genes in the lateral plate mesoderm are somehow related to the specification of limb-forming fields [7]. Furthermore, the positioning of the forelimb buds at approximately the anterior border of the expression domains of Hox 5 and Hox 6 in the lateral plate mesoderm is conserved among zebrafish, chick and mouse [5,59-61]. Recently, it was shown that Hox proteins are involved in the regulation of the transcription of T-box transcription factor 5 (Tbx5) (Figure 3) [11,12,49]. Tbx5 is expressed in the anterior paired appendages of zebrafish, chick and mouse embryos [62-64] and initiates forelimb development [12,65-69]. In humans, mutations in TBX5 cause Holt-Oram syndrome (OMIM 142900), an autosomal-dominant disorder characterized by abnormalities of the upper limbs and cardiac defects [70,71]. Zebrafish with mutations in $p b x 4$, which encodes a Hox protein co-factor, fail to induce $t b x 5$ expression or initiate formation of pectoral fin buds [72]. In addition, developmental and molecular analyses of chick and mouse embryos revealed that rostral Hox genes expressed in the lateral plate mesoderm directly regulate the expression of $T b x 5$ and thereby control the axial position of forelimb-forming fields (Figure 3) [11].

Recent analyses of mouse mutants showed that Hox 5 and Hox9 genes are involved in establishing the anterior and posterior domains of the forelimb, respectively [73,74]. Loss of function of all three Hox 5 genes leads to anterior forelimb defects resulting from derepression of Shh expression [73]. In the anterior forelimbs, Hox 5 proteins interact with promyelocytic leukemia zinc finger (Plzf) and cooperatively mediate repression of Shh expression [73]. In contrast, an analysis of a Hox9 quadruple knockout revealed that axial Hox9 paralogs establish the posterior field of forelimbs by triggering the posteriorly restricted expression of Hand2, which directly activates Shh at the posterior margin [74].

In chick and zebrafish, Wnt/ $\beta$-catenin signaling has key roles in the initiation of limb formation $[67,75]$. In chick embryos, Wnt $2 b$ is expressed in the intermediate mesoderm and the lateral plate mesoderm in the presumptive forelimb-forming region, whereas $W n t 8 \mathrm{c}$ is expressed in the presumptive hindlimb-forming region [75], and the implantation of Wnt2b- or Wnt8c-expressing cells into the interlimb flank region leads to the formation of an additional limb via induction of ectopic Fgf10 expression [75]. Consistent with this result, zebrafish embryos injected with wnt $2 b$ 
morpholinos show downregulation of $t b x 5$ expression and fail to form pectoral fin buds [67]. In mouse embryos, however, Wnt ligands that act upstream of Fgf10 in the limb-forming field have not yet been found. Furthermore, double knockout mice for both Lef1 and Tcf1, which mediate Wnt signaling by forming a complex with $\beta$-catenin, form normal limb buds [76]. However, a recent study in mice showed that conditional removal of $\beta$-catenin from forelimb-forming regions leads to the reduction of $T b x 5$ expression and incomplete forelimbs, suggesting that the function of $\beta$-catenin to regulate $T b x 5$ transcription is conserved among zebrafish, chick and mouse [50]. The T-cell factor/lymphoid enhancer factor (TCF/LEF) binding sequence is required for the enhancer activity of the forelimb-specific $T b x 5$ regulatory element, suggesting that $\beta$-catenin directly regulates $T b x 5$ expression [50]. Furthermore, retinoic acid signaling directly activates transcription of $T b x 5$ in the forelimb-forming fields (Figure 3) [50]. Taken together, retinoic acid signaling, $\beta$-catenin/LEF/TCF and anteriorly nested Hox proteins seem to cooperatively activate Tbx5 transcription for inducing forelimb bud formation [50].

It has also been shown that caudally expressed Hox proteins, such as Hoxc8, Hoxc9 and Hoxc10, can form a repressive complex and bind to the forelimb-specific regulatory sequences of $T b x 5$ and repress its expression [49]. Interestingly, in chick embryos, transplantation of an Fgf-soaked bead into the interlimb flank region turns off Hoxc9 expression when an ectopic wing bud is induced, whereas it turns on Hoxc9 expression when an ectopic leg bud is induced [7]. Thus, these previous findings seem to support the view that Hoxc9 acts as a repressor of $T b x 5$ transcription [49]. In addition, rostrally expanded Hoxc8 distribution is present in the body trunk of a limbless vertebrate, the python [77], supporting the view that $H o x c 8$ represses Tbx5 expression [49].

Molecular mechanisms that specify the hindlimb-forming fields are not as well characterized as those of the forelimb-forming fields. Tbx4, which is closely related to $T b x 5$, is specifically expressed in the presumptive hindlimb forming fields of chick, mouse, teleosts and catshark (Scyliorhinus canicula) $[62-64,78,79]$, and its expression is suggested to be regulated by Hox genes [12] and Pit $x 1[12,80]$. In addition, studies on transgenic mice, in which $T b x 5$ is replaced by $T b x 4$, revealed that $T b x 4$ is able to substitute for $T b x 5$ function in the initiation of the forelimb bud [12], suggesting that Tbx4 has a similar role in the initiation of hindlimb formation. However, unlike Tbx5 null mutants, mice deficient for Tbx4 are able to initiate F $g$ f10 expression in hindlimb fields and form truncated hindlimbs [81]. Additional studies in mice deficient for Tbx4 revealed that $T b x 4$ is crucial for initiating hindlimb outgrowth, but an additional factor(s) other than $T b x 4$ is likely to be involved in this process [82]. Islet1, a LIM-homeodomain transcription factor that is specifically expressed in the hindlimb progenitors, was recently shown to be required for hindlimb initiation $[83,84]$. Early inactivation of Islet 1 as well as $\beta$-catenin in the lateral plate mesoderm leads to a failure to initiate hindlimb development [84]. Furthermore, Islet1 is required for the nuclear accumulation of $\beta$-catenin and thereby for activation of the $\beta$-catenin pathway, and that the $\beta$-catenin pathway is required for the maintenance of Islet1 expression [84]. Islet1 seems to be a missing piece in the regulation of hindlimb-specific initiation [84].

Pitx1, which encodes a member of the paired-like family of homeodomain transcription factors, is expressed in the presumptive hindlimb-forming fields in chick, mouse, stickleback (Gasterosteus aculeatus) and catshark embryos [79,85-87]. In mice, Pitx 1 is required for normal initiation of hindlimb development by regulating transcription levels of $T b x 4[85,88,89]$. It has recently been suggested that in Liebenberg syndrome (OMIM 186550) [90], an autosomal-dominant malformation of the upper limbs, the upper limbs have undergone a partial homeotic hindlimb transformation, and that this phenotype is associated with genomic rearrangements at the PITX1 locus [91].

In teleosts, the roles of $t b x 4$ and pit $x 1$ in pelvic fin formation seem to be more critical than their roles in the hindlimb formation of amniotes. In $t b x 4$ mutant zebrafish, expression of $f g f 10$ is not induced, and thus pelvic fin buds fail to initiate their formation at a very early stage of fin initiation [92]. In the spine-deficient morph of the three-spined sticklebacks, expressions of neither pit 1 nor $t b x 4$ are detected in the lateral plate mesoderm at the level of the pelvic fin, and pelvic fin buds fail to initiate their 
formation [87]. Subsequently, the responsible regulatory sequence for pelvic spine deficiency was found within the pelvic fin-specific enhancer of pitx 1 in three-spined stickleback $[93,94]$. In teleosts, pelvic fin formation is significantly delayed as it is triggered by thyroid hormone at the time of the larva-juvenile transition [95] (for instance, three weeks post-fertilization in zebrafish). Thus, the levels of molecules that affect the limb initiation process in the pelvic fin-forming region of teleosts at the time of pelvic fin initiation are not identical to those in the presumptive hindlimb-forming region of early chick and mouse embryos. Although we cannot exclude the possibility that the functions of Pitx1 and/or Tbx4 in the initiation of pelvic fin/hindlimb development in teleosts are different from those in mice, it is possible that the Pitx1-Tbx4 pathway is sufficient to activate the initiation of pelvic fin outgrowth in teleost fishes.

A shift in limb position is also observed in chick and mouse embryos in which expression of Gdf11 has been manipulated [96,97]. Mutant mice carrying a targeted deletion of Gdf11 exhibit posterior displacement of the hindlimbs, and patterns of expression of Hoxc6, Hoxc10 and Hoxc11 in spinal cord and paraxial mesoderm also shift posteriorly [96]. In chick embryos, overexpression of Gdf11 in the spinal cord leads to the rostral shift of both fore- and hindlimb [97]. In the spinal cord of chicks that overexpress Gdf11, expression of Hoxc6, Hoxc8, Hoxc9 and Hoxc10 shift rostrally and lead to the rostral shift of the lateral motor columns [97], which are defined by Hox6 and Hox10 [98-100]. Thus, the shift in limb buds in chick following the introduction of Gdf11-expressing constructs into the spinal cord was interpreted to be caused by a shift in the lateral motor columns [97]. Gdf11 expression in the caudal part of the body is conserved in chick, mouse, zebrafish and Nile tilapia embryos [101-103]. Furthermore, in zebrafish injected with $g d f 11$ morpholinos, the pelvic fin shifts caudally, along with a posterior shift in Hoxc10 expression in the spinal cord [103], suggesting that the Gdf11-controlled mechanism that positions the hindlimb along the body axis is likely to be conserved in gnathostomes [103,104]. Gdf11 signaling is a central modulator of the trunk-to-tail transition during mouse development [105]. In Gdf11 mutants, the specification of the cloaca and the induction of the hindlimbs are significantly delayed, whereas precocious activation of Gdf11 signaling in the epiblast anteriorizes these structures with a concomitant reduction in trunk length [105]. In contrast, precocious activation of genes of the Hox9, Hox10 and Hox11 groups in the epiblast do not alter the phenotype, with one exception: transgenic mice expressing Hoxb9 show only a slight anterior displacement of the hindlimbs by one somite [105]. Thus, Jurberg and his colleagues proposed that Hox genes do not play a major role in specifying the hindlimb position along the anterior-posterior axis during the trunk-to-tail transition [105]. In early stages of hindlimb induction, Islet1 has a major role in establishing the posterior hindlimb field by regulating the Hand2-Shh pathway $[84,106]$. During the trunk-to-tail transition, Gdf11 directly activates Islet1 to promote formation of the most posterior progenitors of the lateral plate mesoderm, such as the hindlimbs and cloacal tissue [105].

It has been suggested that the nested Hox gene expression in the lateral plate mesoderm is necessary for acquiring the first pair of appendages during the evolution of vertebrates [107]. In limbless amphioxus species Branchiostoma floridae and Branchiostoma lanceolatum, Tbx4/5 is expressed throughout the ventral mesoderm (Figure 3) [108,109]. Interestingly, amphioxus Tbx4/5 has the ability to initiate forelimb formation in mouse transgenic lines [110]. This apparent contradiction can be explained by the regionalization of the ventral mesoderm and expression of Hox genes mentioned above. In amphioxus, the ventral mesoderm is not molecularly regionalized into the cardiac and posterior ventral mesoderm [4], and Hox genes are not expressed in the ventral mesoderm progenitors [51,52], suggesting that $T b \times 4 / 5$ in the ventral mesoderm may contribute only to heart formation in amphioxus [4]. In lampreys, the lateral plate mesoderm is regionalized into the ALPM and the PLPM, and LjHox5i and LjHox6w are expressed in the PLPM in a nested fashion [4]. Nevertheless, lamprey $L j T b x 4 / 5$ transcripts are not present in the PLPM but are in the ALPM [4,37]. Although we do not know whether lamprey Hox genes have the conserved function of inducing Tbx4/5 in the PLPM, one of the main reasons for limblessness seems to be the lack of separation of the PLPM into the 
somatic and splanchnic layers (Figure 3), which results in the contribution of cells from the PLPM to the peritoneal epithelium but not to the body wall $[4,57]$.

\section{Conclusions}

In gnathostomes, the lateral plate mesoderm is regionalized into the ALPM and PLPM, and Hox genes are expressed in a nested fashion along the anterior-posterior axis in the PLPM. Then, the lateral plate mesoderm splits into the somatic and splanchnic layers, and the expression of limb initiation genes appears in the limb-forming fields. Figure 4 summarizes the genes implicated in the specification of limb-forming fields in the PLPM during mouse development. Tbx5 and Tbx4 are expressed in the forelimb- and hindlimb-forming fields, respectively $[63,64]$, and play crucial roles in the initiation of limb outgrowth [12,65-69]. In the forelimb-forming field, retinoic acid signaling and $\beta$-catenin signaling act cooperatively with rostrally expressed Hox genes to directly regulate $T b x 5$ expression [11,50], whereas caudally expressed Hox genes repress Tbx5 to restrict its expression to this field [49]. In the hindlimb-forming field, Tbx4 expression, which is crucial for the induction of hindlimb development, is suggested to be activated by Hox genes [12] and Pitx1 [12,85]. Islet1-mediated activation of $\beta$-catenin signaling is also required for hindlimb induction [84]. In the early forelimb field, Hox9 paralogous genes are required for the expression of Hand2 to establish the posterior domain [74], whereas Hox 5 genes and Plzf cooperatively mediate repression of Shh expression in the anterior domain [73]. In contrast, the hindlimb posterior domain is established by Islet1 to regulate Hand2 expression in this region [106].

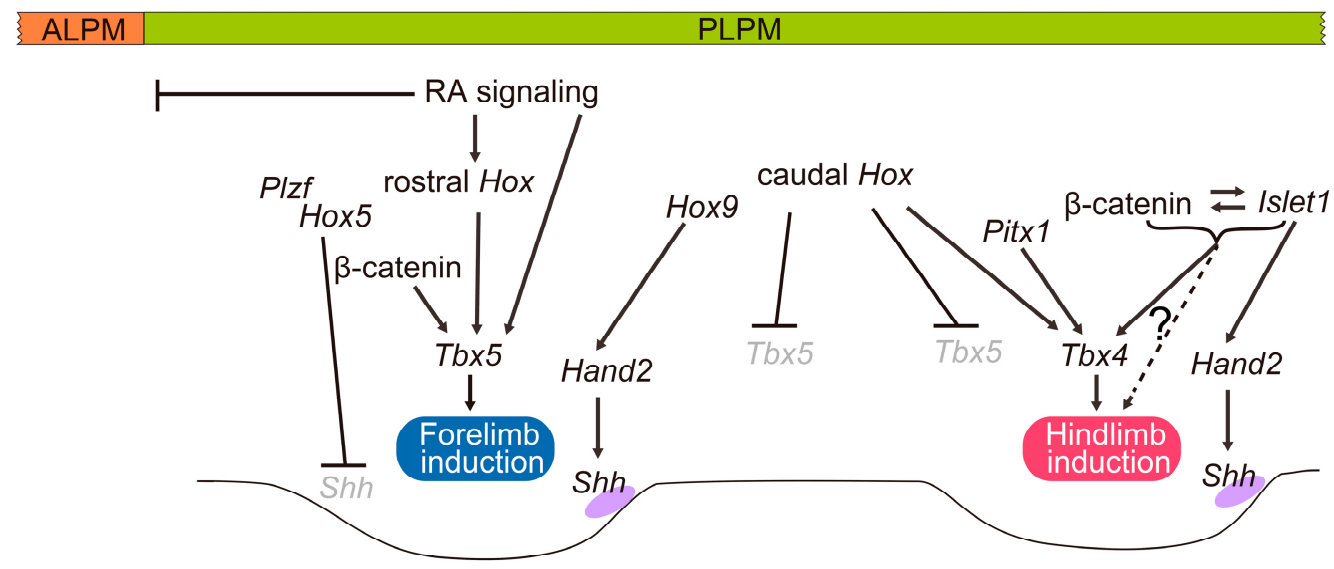

Figure 4. Genes implicated in the specification of the limb field during development of mouse embryos. Retinoic acid signaling is involved in the regionalization of the LPM into the ALPM and PLPM. In the PLPM, Tbx5 and Tbx4, which are expressed in forelimb- and hindlimb-forming regions, respectively, play pivotal roles in limb initiation. Nested expression of Hox genes seems to be involved in the regionalization of the PLPM into forelimb, interlimb flank and hindlimb fields. In the forelimb level, rostrally expressed Hox proteins, retinoic acid signaling and $\beta$-catenin signaling cooperatively activate Tbx 5 transcription. Whereas caudally expressed Hox genes repress $T b x 5$ to restrict its expression to the forelimb level, Hox genes and Pit $x 1$ have been suggested to activate Tbx4 expression at the hindlimb level. Islet 1 is also required for hindlimb initiation. Islet1 is required for the nuclear accumulation of $\beta$-catenin, and $\beta$-catenin is required for the maintenance of Islet1 expression. In the forelimb posterior domain, Hox 9 genes are required to trigger Hand2 expression in this region. In the forelimb anterior domain, Hox 5 genes and Plzf cooperatively mediate repression of Shh expression. In the hindlimb posterior domain, Islet 1 activates Hand 2 expression. It should be noted that the roles of Hox genes, RA signaling and $\beta$-catenin signaling are disputed. See text for references and details.

Developmental analyses of limbless amphioxus and lampreys have provided clues to understand the evolutionary scenarios that led to the acquisition of limb-forming fields in the vertebrate body [4]. 
In amphioxus, the ventral mesoderm is not molecularly regionalized into cardiac versus posterior ventral mesoderm. In lamprey, the lateral plate mesoderm is regionalized into the ALPM and the PLPM, and Hox genes are expressed in a nested fashion in the PLPM [4], but the PLPM is not separated into the somatic and splanchnic layers [4]. These past and current findings suggest that, to acquire the limb-forming fields, novel expression domains of limb initiation genes in the lateral plate mesoderm, regionalization along its anterior-posterior axis, and its subdivision into somatic and splanchnic layers were likely to be required during vertebrate evolution.

Acknowledgments: The author thanks past and current members of the Tanaka laboratory and many collaborators for their contribution to the studies cited here. Portions of the studies conducted in the Tanaka laboratory were supported by a Grant-in-Aid for Scientific Research (B) 25291086, the Takeda Foundation, the Naito Foundation and the Inamori Foundation.

Conflicts of Interest: The author declares no conflict of interest. The funding sponsors had no role in the design of the study; in the collection, analyses, or interpretation of data; in the writing of the manuscript; and in the decision to publish the results.

\section{References}

1. Coates, M.I. The origin of vertebrate limbs. Dev. Suppl. 1994, 169-180.

2. Janvier, P. Early Vertebrates; Clarendon Press: Oxford, UK, 1996.

3. Donoghue, P.C.; Forey, P.L.; Aldridge, R.J. Conodont affinity and chordate phylogeny. Biol. Rev. Camb. Philos. Soc. 2000, 75, 191-251. [CrossRef] [PubMed]

4. Onimaru, K.; Shoguchi, E.; Kuratani, S.; Tanaka, M. Development and evolution of the lateral plate mesoderm: Comparative analysis of amphioxus and lamprey with implications for the acquisition of paired fins. Dev. Biol. 2011, 359, 124-136. [CrossRef] [PubMed]

5. Waxman, J.S.; Keegan, B.R.; Roberts, R.W.; Poss, K.D.; Yelon, D. Hoxb5b acts downstream of retinoic acid signaling in the forelimb field to restrict heart field potential in zebrafish. Dev. Cell 2008, 15, 923-934. [CrossRef] [PubMed]

6. Zhao, X.; Sirbu, I.O.; Mic, F.A.; Molotkova, N.; Molotkov, A.; Kumar, S.; Duester, G. Retinoic acid promotes limb induction through effects on body axis extension but is unnecessary for limb patterning. Curr. Biol. 2009, 19, 1050-1057. [CrossRef] [PubMed]

7. Cohn, M.J.; Patel, K.; Krumlauf, R.; Wilkinson, D.G.; Clarke, J.D.; Tickle, C. Hox 9 genes and vertebrate limb specification. Nature 1997, 387, 97-101. [CrossRef] [PubMed]

8. Nowicki, J.L.; Burke, A.C. Hox genes and morphological identity: Axial versus lateral patterning in the vertebrate mesoderm. Development 2000, 127, 4265-4275. [PubMed]

9. Funayama, N.; Sato, Y.; Matsumoto, K.; Ogura, T.; Takahashi, Y. Coelom formation: Binary decision of the lateral plate mesoderm is controlled by the ectoderm. Development 1999, 126, 4129-4138. [PubMed]

10. Logan, M. Finger or toe: The molecular basis of limb identity. Development 2003, 130, 6401-6410. [CrossRef] [PubMed]

11. Minguillon, C.; Nishimoto, S.; Wood, S.; Vendrell, E.; Gibson-Brown, J.J.; Logan, M.P. Hox genes regulate the onset of Tbx5 expression in the forelimb. Development 2012, 139, 3180-3188. [CrossRef] [PubMed]

12. Minguillon, C.; del Buono, J.; Logan, M.P. Tbx5 and Tbx4 are not sufficient to determine limb-specific morphologies but have common roles in initiating limb outgrowth. Dev. Cell 2005, 8, 75-84. [CrossRef] [PubMed]

13. Grandel, H.; Lun, K.; Rauch, G.J.; Rhinn, M.; Piotrowski, T.; Houart, C.; Sordino, P.; Kuchler, A.M.; Schulte-Merker, S.; Geisler, R.; et al. Retinoic acid signalling in the zebrafish embryo is necessary during pre-segmentation stages to pattern the anterior-posterior axis of the CNS and to induce a pectoral fin bud. Development 2002, 129, 2851-2865. [PubMed]

14. Gibert, Y.; Gajewski, A.; Meyer, A.; Begemann, G. Induction and prepatterning of the zebrafish pectoral fin bud requires axial retinoic acid signaling. Development 2006, 133, 2649-2659. [CrossRef] [PubMed]

15. Bruce, A.E.; Oates, A.C.; Prince, V.E.; Ho, R.K. Additional hox clusters in the zebrafish: Divergent expression patterns belie equivalent activities of duplicate hoxB5 genes. Evol. Dev. 2001, 3, 127-144. [CrossRef] [PubMed] 
16. Oosterveen, T.; Niederreither, K.; Dolle, P.; Chambon, P.; Meijlink, F.; Deschamps, J. Retinoids regulate the anterior expression boundaries of 5' Hoxb genes in posterior hindbrain. EMBO J. 2003, 22, 262-269. [CrossRef] [PubMed]

17. Sharpe, J.; Nonchev, S.; Gould, A.; Whiting, J.; Krumlauf, R. Selectivity, sharing and competitive interactions in the regulation of hoxb genes. EMBO J. 1998, 17, 1788-1798. [CrossRef] [PubMed]

18. Rancourt, D.E.; Tsuzuki, T.; Capecchi, M.R. Genetic interaction between hoxb-5 and hoxb-6 is revealed by nonallelic noncomplementation. Genes Dev. 1995, 9, 108-122. [CrossRef] [PubMed]

19. Ryckebusch, L.; Wang, Z.; Bertrand, N.; Lin, S.C.; Chi, X.; Schwartz, R.; Zaffran, S.; Niederreither, K. Retinoic acid deficiency alters second heart field formation. Proc. Natl. Acad. Sci. USA 2008, 105, 2913-2918. [CrossRef] [PubMed]

20. Searcy, R.D.; Yutzey, K.E. Analysis of Hox gene expression during early avian heart development. Dev. Dyn. 1998, 213, 82-91. [CrossRef]

21. Lo, P.C.; Frasch, M. Establishing A-P polarity in the embryonic heart tube: A conserved function of hox genes in Drosophila and vertebrates? Trends Cardiovasc. Med. 2003, 13, 182-187. [CrossRef]

22. Chisaka, O.; Capecchi, M.R. Regionally restricted developmental defects resulting from targeted disruption of the mouse homeobox gene hox-1.5. Nature 1991, 350, 473-479. [CrossRef] [PubMed]

23. Rosenthal, N.; Xavier-Neto, J. From the bottom of the heart: Anteroposterior decisions in cardiac muscle differentiation. Curr. Opin. Cell Biol. 2000, 12, 742-746. [CrossRef]

24. Bertrand, N.; Roux, M.; Ryckebusch, L.; Niederreither, K.; Dolle, P.; Moon, A.; Capecchi, M.; Zaffran, S. Hox genes define distinct progenitor sub-domains within the second heart field. Dev. Biol. 2011, 353, $266-274$. [CrossRef] [PubMed]

25. Stratford, T.; Horton, C.; Maden, M. Retinoic acid is required for the initiation of outgrowth in the chick limb bud. Curr. Biol. 1996, 6, 1124-1133. [CrossRef]

26. Mic, F.A.; Haselbeck, R.J.; Cuenca, A.E.; Duester, G. Novel retinoic acid generating activities in the neural tube and heart identified by conditional rescue of Raldh2 null mutant mice. Development 2002, 129, 2271-2282. [PubMed]

27. Niederreither, K.; Subbarayan, V.; Dolle, P.; Chambon, P. Embryonic retinoic acid synthesis is essential for early mouse post-implantation development. Nat. Genet. 1999, 21, 444-448. [CrossRef] [PubMed]

28. Cunningham, T.J.; Zhao, X.; Sandell, L.L.; Evans, S.M.; Trainor, P.A.; Duester, G. Antagonism between retinoic acid and fibroblast growth factor signaling during limb development. Cell Rep. 2013, 3, 1503-1511. [CrossRef] [PubMed]

29. Marques, S.R.; Lee, Y.; Poss, K.D.; Yelon, D. Reiterative roles for fgf signaling in the establishment of size and proportion of the zebrafish heart. Dev. Biol. 2008, 321, 397-406. [CrossRef] [PubMed]

30. Holland, N.D.; Venkatesh, T.V.; Holland, L.Z.; Jacobs, D.K.; Bodmer, R. Amphink2-tin, an amphioxus homeobox gene expressed in myocardial progenitors: Insights into evolution of the vertebrate heart. Dev. Biol. 2003, 255, 128-137. [CrossRef]

31. Charite, J.; McFadden, D.G.; Olson, E.N. The bHLH transcription factor dHand controls Sonic hedgehog expression and establishment of the zone of polarizing activity during limb development. Development 2000, 127, 2461-2470. [PubMed]

32. Deimling, S.J.; Drysdale, T.A. Retinoic acid regulates anterior-posterior patterning within the lateral plate mesoderm of Xenopus. Mech. Dev. 2009, 126, 913-923. [CrossRef] [PubMed]

33. Yelon, D.; Ticho, B.; Halpern, M.E.; Ruvinsky, I.; Ho, R.K.; Silver, L.M.; Stainier, D.Y. The bHLH transcription factor hand2 plays parallel roles in zebrafish heart and pectoral fin development. Development 2000, 127, 2573-2582. [PubMed]

34. Buchberger, A.; Pabst, O.; Brand, T.; Seidl, K.; Arnold, H.H. Chick NKx-2.3 represents a novel family member of vertebrate homologues to the Drosophila homeobox gene tinman: Differential expression of cNKx-2.3 and cNKkx-2.5 during heart and gut development. Mech. Dev. 1996, 56, 151-163. [CrossRef]

35. Kraus, F.; Haenig, B.; Kispert, A. Cloning and expression analysis of the mouse T-box gene tbx20. Mech. Dev. 2001, 100, 87-91. [CrossRef]

36. Yamagishi, T.; Nakajima, Y.; Nishimatsu, S.; Nohno, T.; Ando, K.; Nakamura, H. Expression of tbx20 rna during chick heart development. Dev. Dyn. 2004, 230, 576-580. [CrossRef] [PubMed] 
37. Kokubo, N.; Matsuura, M.; Onimaru, K.; Tiecke, E.; Kuraku, S.; Kuratani, S.; Tanaka, M. Mechanisms of heart development in the japanese lamprey, lethenteron japonicum. Evol. Dev. 2010, 12, 34-44. [CrossRef] [PubMed]

38. Tanaka, M. Molecular and evolutionary basis of limb field specification and limb initiation. Dev. Growth Differ. 2013, 55, 149-163. [CrossRef] [PubMed]

39. Garg, V.; Yamagishi, C.; Hu, T.; Kathiriya, I.S.; Yamagishi, H.; Srivastava, D. Tbx1, a digeorge syndrome candidate gene, is regulated by sonic hedgehog during pharyngeal arch development. Dev. Biol. 2001, 235, 62-73. [CrossRef] [PubMed]

40. Tiecke, E.; Matsuura, M.; Kokubo, N.; Kuraku, S.; Kusakabe, R.; Kuratani, S.; Tanaka, M. Identification and developmental expression of two Tbx1/10-related genes in the agnathan lethenteron japonicum. Dev. Genes Evol. 2007, 217, 691-697. [CrossRef] [PubMed]

41. Meulemans, D.; Bronner-Fraser, M. Insights from amphioxus into the evolution of vertebrate cartilage. PLOS ONE 2007, 2, e787. [CrossRef] [PubMed]

42. Escriva, H.; Bertrand, S.; Germain, P.; Robinson-Rechavi, M.; Umbhauer, M.; Cartry, J.; Duffraisse, M.; Holland, L.; Gronemeyer, H.; Laudet, V. Neofunctionalization in vertebrates: The example of retinoic acid receptors. PLoS Genet. 2006, 2, e102. [CrossRef] [PubMed]

43. Castillo, H.A.; Cravo, R.M.; Azambuja, A.P.; Simoes-Costa, M.S.; Sura-Trueba, S.; Gonzalez, J.; Slonimsky, E.; Almeida, K.; Abreu, J.G.; de Almeida, M.A.; et al. Insights into the organization of dorsal spinal cord pathways from an evolutionarily conserved raldh2 intronic enhancer. Development 2010, 137, 507-518. [CrossRef] [PubMed]

44. Koop, D.; Chen, J.; Theodosiou, M.; Carvalho, J.E.; Alvarez, S.; de Lera, A.R.; Holland, L.Z.; Schubert, M. Roles of retinoic acid and Tbx1/10 in pharyngeal segmentation: Amphioxus and the ancestral chordate condition. EvoDevo 2014, 5, 36. [CrossRef] [PubMed]

45. Schubert, M.; Holland, N.D.; Laudet, V.; Holland, L.Z. A retinoic acid-Hox hierarchy controls both anterior/posterior patterning and neuronal specification in the developing central nervous system of the cephalochordate amphioxus. Dev. Biol. 2006, 296, 190-202. [CrossRef] [PubMed]

46. Murakami, Y.; Pasqualetti, M.; Takio, Y.; Hirano, S.; Rijli, F.M.; Kuratani, S. Segmental development of reticulospinal and branchiomotor neurons in lamprey: Insights into the evolution of the vertebrate hindbrain. Development 2004, 131, 983-995. [CrossRef] [PubMed]

47. Kuratani, S.; Ueki, T.; Hirano, S.; Aizawa, S. Rostral truncation of a cyclostome, lampetra japonica, induced by all-trans retinoic acid defines the head/trunk interface of the vertebrate body. Dev. Dyn. 1998, 211, 35-51. [CrossRef]

48. Bertrand, S.; Aldea, D.; Oulion, S.; Subirana, L.; de Lera, A.R.; Somorjai, I.; Escriva, H. Evolution of the role of RA and FGF signals in the control of somitogenesis in chordates. PLoS ONE 2015, 10, e0136587. [CrossRef] [PubMed]

49. Nishimoto, S.; Minguillon, C.; Wood, S.; Logan, M.P. A combination of activation and repression by a colinear Hox code controls forelimb-restricted expression of Tbx5 and reveals hox protein specificity. PLoS Genet. 2014, 10, e1004245. [CrossRef] [PubMed]

50. Nishimoto, S.; Wilde, S.M.; Wood, S.; Logan, M.P. RA acts in a coherent feed-forward mechanism with Tbx5 to control limb bud induction and initiation. Cell Rep. 2015, 12, 879-891. [CrossRef] [PubMed]

51. Holland, P.W.; Holland, L.Z.; Williams, N.A.; Holland, N.D. An amphioxus homeobox gene: Sequence conservation, spatial expression during development and insights into vertebrate evolution. Development 1992, 116, 653-661. [PubMed]

52. Wada, H.; Garcia-Fernandez, J.; Holland, P.W. Colinear and segmental expression of amphioxus Hox genes. Dev. Biol. 1999, 213, 131-141. [CrossRef] [PubMed]

53. Schubert, M.; Yu, J.K.; Holland, N.D.; Escriva, H.; Laudet, V.; Holland, L.Z. Retinoic acid signaling acts via Hox1 to establish the posterior limit of the pharynx in the chordate amphioxus. Development 2005, 132, 61-73. [CrossRef] [PubMed]

54. Schubert, M.; Holland, N.D.; Escriva, H.; Holland, L.Z.; Laudet, V. Retinoic acid influences anteroposterior positioning of epidermal sensory neurons and their gene expression in a developing chordate (amphioxus). Proc. Nat. Acad. Sci. USA 2004, 101, 10320-10325. [CrossRef] [PubMed] 
55. Koop, D.; Holland, N.D.; Semon, M.; Alvarez, S.; de Lera, A.R.; Laudet, V.; Holland, L.Z.; Schubert, M. Retinoic acid signaling targets Hox genes during the amphioxus gastrula stage: Insights into early anterior-posterior patterning of the chordate body plan. Dev. Biol. 2010, 338, 98-106. [CrossRef] [PubMed]

56. Tanaka, M.; Yu, R.; Kurokawa, D. Anterior migration of lateral plate mesodermal cells during embryogenesis of the pufferfish Takifugu niphobles: Insight into the rostral positioning of pelvic fins. J. Anat. 2015, 227, 81-88. [CrossRef] [PubMed]

57. Tulenko, F.J.; McCauley, D.W.; Mackenzie, E.L.; Mazan, S.; Kuratani, S.; Sugahara, F.; Kusakabe, R.; Burke, A.C. Body wall development in lamprey and a new perspective on the origin of vertebrate paired fins. Proc. Nat. Acad. Sci. USA 2013, 110, 11899-11904. [CrossRef] [PubMed]

58. Kaltenbach, S.L.; Holland, L.Z.; Holland, N.D.; Koop, D. Developmental expression of the three iroquois genes of amphioxus (BfIrxa, BfIrxb, and BfIrxc) with special attention to the gastrula organizer and anteroposterior boundaries in the central nervous system. Gene Expr. Patterns 2009, 9, 329-334. [CrossRef] [PubMed]

59. Oliver, G.; Wright, C.V.; Hardwicke, J.; de Robertis, E.M. A gradient of homeodomain protein in developing forelimbs of Xenopus and mouse embryos. Cell 1988, 55, 1017-1024. [CrossRef]

60. Becker, D.; Eid, R.; Schughart, K. The limb/lpm enhancer of the murine Hoxb6 gene: Reporter gene analysis in transgenic embryos and studies of DNA-protein interactions. Pharm. Acta Helv. 1996, 71, 29-35. [CrossRef]

61. Nelson, C.E.; Morgan, B.A.; Burke, A.C.; Laufer, E.; DiMambro, E.; Murtaugh, L.C.; Gonzales, E.; Tessarollo, L.; Parada, L.F.; Tabin, C. Analysis of Hox gene expression in the chick limb bud. Development 1996, 122, 1449-1466. [PubMed]

62. Tamura, K.; Yonei-Tamura, S.; Belmonte, J.C. Differential expression of Tbx4 and Tbx5 in zebrafish fin buds. Mech. Dev. 1999, 87, 181-184. [CrossRef]

63. Gibson-Brown, J.J.; Agulnik, S.I.; Chapman, D.L.; Alexiou, M.; Garvey, N.; Silver, L.M.; Papaioannou, V.E. Evidence of a role for T-box genes in the evolution of limb morphogenesis and the specification of forelimb/hindlimb identity. Mech. Dev. 1996, 56, 93-101. [CrossRef]

64. Isaac, A.; Rodriguez-Esteban, C.; Ryan, A.; Altabef, M.; Tsukui, T.; Patel, K.; Tickle, C.; Izpisua-Belmonte, J.C. Tbx genes and limb identity in chick embryo development. Development 1998, 125, 1867-1875. [PubMed]

65. Ahn, D.G.; Kourakis, M.J.; Rohde, L.A.; Silver, L.M.; Ho, R.K. T-box gene tbx5 is essential for formation of the pectoral limb bud. Nature 2002, 417, 754-758. [CrossRef] [PubMed]

66. Garrity, D.M.; Childs, S.; Fishman, M.C. The heartstrings mutation in zebrafish causes heart/fin Tbx5 deficiency syndrome. Development 2002, 129, 4635-4645. [PubMed]

67. Ng, J.K.; Kawakami, Y.; Buscher, D.; Raya, A.; Itoh, T.; Koth, C.M.; Rodriguez Esteban, C.; Rodriguez-Leon, J.; Garrity, D.M.; Fishman, M.C.; et al. The limb identity gene Tbx5 promotes limb initiation by interacting with Wnt2b and Fgf10. Development 2002, 129, 5161-5170. [PubMed]

68. Agarwal, P.; Wylie, J.N.; Galceran, J.; Arkhitko, O.; Li, C.; Deng, C.; Grosschedl, R.; Bruneau, B.G. Tbx5 is essential for forelimb bud initiation following patterning of the limb field in the mouse embryo. Development 2003, 130, 623-633. [CrossRef] [PubMed]

69. Rallis, C.; Bruneau, B.G.; del Buono, J.; Seidman, C.E.; Seidman, J.G.; Nissim, S.; Tabin, C.J.; Logan, M.P. Tbx5 is required for forelimb bud formation and continued outgrowth. Development 2003, 130, 2741-2751. [CrossRef] [PubMed]

70. Basson, C.T.; Bachinsky, D.R.; Lin, R.C.; Levi, T.; Elkins, J.A.; Soults, J.; Grayzel, D.; Kroumpouzou, E.; Traill, T.A.; Leblanc-Straceski, J.; et al. Mutations in human TBX5 [corrected] cause limb and cardiac malformation in holt-oram syndrome. Nat. Genet. 1997, 15, 30-35. [CrossRef] [PubMed]

71. Li, Q.Y.; Newbury-Ecob, R.A.; Terrett, J.A.; Wilson, D.I.; Curtis, A.R.; Yi, C.H.; Gebuhr, T.; Bullen, P.J.; Robson, S.C.; Strachan, T.; et al. Holt-oram syndrome is caused by mutations in TBX5, a member of the Brachyury (T) gene family. Nat. Genet. 1997, 15, 21-29. [CrossRef] [PubMed]

72. Popperl, H.; Rikhof, H.; Chang, H.; Haffter, P.; Kimmel, C.B.; Moens, C.B. Lazarus is a novel pbx gene that globally mediates hox gene function in zebrafish. Mol. Cell 2000, 6, 255-267. [CrossRef]

73. Xu, B.; Hrycaj, S.M.; McIntyre, D.C.; Baker, N.C.; Takeuchi, J.K.; Jeannotte, L.; Gaber, Z.B.; Novitch, B.G.; Wellik, D.M. Hox 5 interacts with Plzf to restrict Shh expression in the developing forelimb. Proc. Nat. Acad. Sci. USA 2013, 110, 19438-19443. [CrossRef] [PubMed]

74. Xu, B.; Wellik, D.M. Axial Hox9 activity establishes the posterior field in the developing forelimb. Proc. Nat. Acad. Sci. USA 2011, 108, 4888-4891. [CrossRef] [PubMed] 
75. Kawakami, Y.; Capdevila, J.; Buscher, D.; Itoh, T.; Rodriguez Esteban, C.; Izpisua Belmonte, J.C. Wnt signals control FGF-dependent limb initiation and aer induction in the chick embryo. Cell 2001, 104, 891-900. [CrossRef]

76. Galceran, J.; Hsu, S.C.; Grosschedl, R. Rescue of a wnt mutation by an activated form of LEF-1: Regulation of maintenance but not initiation of brachyury expression. Proc. Nat. Acad. Sci. USA 2001, 98, 8668-8673. [CrossRef] [PubMed]

77. Cohn, M.J.; Tickle, C. Developmental basis of limblessness and axial patterning in snakes. Nature 1999, 399, 474-479. [CrossRef] [PubMed]

78. Tanaka, M.; Munsterberg, A.; Anderson, W.G.; Prescott, A.R.; Hazon, N.; Tickle, C. Fin development in a cartilaginous fish and the origin of vertebrate limbs. Nature 2002, 416, 527-531. [CrossRef] [PubMed]

79. Tanaka, M.; Hale, L.A.; Amores, A.; Yan, Y.L.; Cresko, W.A.; Suzuki, T.; Postlethwait, J.H. Developmental genetic basis for the evolution of pelvic fin loss in the pufferfish takifugu rubripes. Dev. Biol. 2005, 281, 227-239. [CrossRef] [PubMed]

80. Marcil, A.; Dumontier, E.; Chamberland, M.; Camper, S.A.; Drouin, J. Pitx1 and Pitx2 are required for development of hindlimb buds. Development 2003, 130, 45-55. [CrossRef] [PubMed]

81. Naiche, L.A.; Papaioannou, V.E. Loss of Tbx4 blocks hindlimb development and affects vascularization and fusion of the allantois. Development 2003, 130, 2681-2693. [CrossRef] [PubMed]

82. Naiche, L.A.; Papaioannou, V.E. Tbx4 is not required for hindlimb identity or post-bud hindlimb outgrowth. Development 2007, 134, 93-103. [CrossRef] [PubMed]

83. Yang, L.; Cai, C.L.; Lin, L.; Qyang, Y.; Chung, C.; Monteiro, R.M.; Mummery, C.L.; Fishman, G.I.; Cogen, A.; Evans, S. Isl1cre reveals a common bmp pathway in heart and limb development. Development 2006, 133, 1575-1585. [CrossRef] [PubMed]

84. Kawakami, Y.; Marti, M.; Kawakami, H.; Itou, J.; Quach, T.; Johnson, A.; Sahara, S.; O’Leary, D.D.; Nakagawa, Y.; Lewandoski, M.; et al. Islet1-mediated activation of the beta-catenin pathway is necessary for hindlimb initiation in mice. Development 2011, 138, 4465-4473. [CrossRef] [PubMed]

85. Lanctot, C.; Moreau, A.; Chamberland, M.; Tremblay, M.L.; Drouin, J. Hindlimb patterning and mandible development require the Ptx1 gene. Development 1999, 126, 1805-1810. [PubMed]

86. Logan, M.; Tabin, C.J. Role of Pitx1 upstream of tbx4 in specification of hindlimb identity. Science 1999, 283, 1736-1739. [CrossRef] [PubMed]

87. Cole, N.J.; Tanaka, M.; Prescott, A.; Tickle, C. Expression of limb initiation genes and clues to the morphological diversification of threespine stickleback. Curr. Biol. 2003, 13, R951-R952. [CrossRef] [PubMed]

88. Szeto, D.P.; Rodriguez-Esteban, C.; Ryan, A.K.; O'Connell, S.M.; Liu, F.; Kioussi, C.; Gleiberman, A.S.; Izpisua-Belmonte, J.C.; Rosenfeld, M.G. Role of the bicoid-related homeodomain factor Pitx1 in specifying hindlimb morphogenesis and pituitary development. Genes Dev. 1999, 13, 484-494. [CrossRef] [PubMed]

89. Duboc, V.; Logan, M.P. Pitx1 is necessary for normal initiation of hindlimb outgrowth through regulation of Tbx4 expression and shapes hindlimb morphologies via targeted growth control. Development 2011, 138, 5301-5309. [CrossRef] [PubMed]

90. Liebenberg, F. A pedigree with unusual anomalies of the elbows, wrists and hands in five generations. S. Afr. Med. J. 1973, 47, 745-748. [PubMed]

91. Spielmann, M.; Brancati, F.; Krawitz, P.M.; Robinson, P.N.; Ibrahim, D.M.; Franke, M.; Hecht, J.; Lohan, S.; Dathe, K.; Nardone, A.M.; et al. Homeotic arm-to-leg transformation associated with genomic rearrangements at the pitx1 locus. Am. J. Hum. Genet. 2012, 91, 629-635. [CrossRef] [PubMed]

92. Don, E.K.; de Jong-Curtain, T.A.; Doggett, K.; Hall, T.E.; Heng, B.; Badrock, A.P.; Winnick, C.; Nicholson, G.A.; Guillemin, G.J.; Currie, P.D.; et al. Genetic basis of hindlimb loss in a naturally occurring vertebrate model. Biol. Open 2016, 5, 359-366. [CrossRef] [PubMed]

93. Shapiro, M.D.; Marks, M.E.; Peichel, C.L.; Blackman, B.K.; Nereng, K.S.; Jonsson, B.; Schluter, D.; Kingsley, D.M. Genetic and developmental basis of evolutionary pelvic reduction in threespine sticklebacks. Nature 2004, 428, 717-723. [CrossRef] [PubMed]

94. Chan, Y.F.; Marks, M.E.; Jones, F.C.; Villarreal, G., Jr.; Shapiro, M.D.; Brady, S.D.; Southwick, A.M.; Absher, D.M.; Grimwood, J.; Schmutz, J.; et al. Adaptive evolution of pelvic reduction in sticklebacks by recurrent deletion of a Pitx1 enhancer. Science 2010, 327, 302-305. [CrossRef] [PubMed] 
95. Tanaka, M. Revealing the mechanisms of the rostral shift of pelvic fins among teleost fishes. Evol. Dev. 2011, 13, 382-390. [CrossRef] [PubMed]

96. McPherron, A.C.; Lawler, A.M.; Lee, S.J. Regulation of anterior/posterior patterning of the axial skeleton by growth/differentiation factor 11. Nat. Genet. 1999, 22, 260-264. [PubMed]

97. Liu, J.P. The function of growth/differentiation factor 11 (gdf11) in rostrocaudal patterning of the developing spinal cord. Development 2006, 133, 2865-2874. [CrossRef] [PubMed]

98. Dasen, J.S.; Liu, J.P.; Jessell, T.M. Motor neuron columnar fate imposed by sequential phases of Hox-c activity. Nature 2003, 425, 926-933. [CrossRef] [PubMed]

99. Shah, V.; Drill, E.; Lance-Jones, C. Ectopic expression of Hoxd10 in thoracic spinal segments induces motoneurons with a lumbosacral molecular profile and axon projections to the limb. Dev. Dyn. 2004, 231, 43-56. [CrossRef] [PubMed]

100. Wu, Y.; Wang, G.; Scott, S.A.; Capecchi, M.R. Hoxc10 and Hoxd10 regulate mouse columnar, divisional and motor pool identity of lumbar motoneurons. Development 2008, 135, 171-182. [CrossRef] [PubMed]

101. Nakashima, M.; Toyono, T.; Akamine, A.; Joyner, A. Expression of growth/differentiation factor 11, a new member of the BMP/TGFbeta superfamily during mouse embryogenesis. Mech. Dev. 1999, 80, 185-189. [CrossRef]

102. Liu, J.P.; Laufer, E.; Jessell, T.M. Assigning the positional identity of spinal motor neurons: Rostrocaudal patterning of Hox-c expression by fgfs, gdf11, and retinoids. Neuron 2001, 32, 997-1012. [CrossRef]

103. Murata, Y.; Tamura, M.; Aita, Y.; Fujimura, K.; Murakami, Y.; Okabe, M.; Okada, N.; Tanaka, M. Allometric growth of the trunk leads to the rostral shift of the pelvic fin in teleost fishes. Dev. Biol. 2010, 347, $236-245$. [CrossRef] [PubMed]

104. Murakami, Y.; Tanaka, M. Evolution of motor innervation to vertebrate fins and limbs. Dev. Biol. 2011, 355, 164-172. [CrossRef] [PubMed]

105. Jurberg, A.D.; Aires, R.; Varela-Lasheras, I.; Novoa, A.; Mallo, M. Switching axial progenitors from producing trunk to tail tissues in vertebrate embryos. Dev. Cell 2013, 25, 451-462. [CrossRef] [PubMed]

106. Itou, J.; Kawakami, H.; Quach, T.; Osterwalder, M.; Evans, S.M.; Zeller, R.; Kawakami, Y. Islet1 regulates establishment of the posterior hindlimb field upstream of the Hand2-Shh morphoregulatory gene network in mouse embryos. Development 2012, 139, 1620-1629. [CrossRef] [PubMed]

107. Coates, M.I.; Cohn, M. Vertebrate axial and appendicular patterning: The early development of paired appendages. Amer. Zool. 1999, 39, 676-685. [CrossRef]

108. Horton, A.C.; Mahadevan, N.R.; Minguillon, C.; Osoegawa, K.; Rokhsar, D.S.; Ruvinsky, I.; de Jong, P.J.; Logan, M.P.; Gibson-Brown, J.J. Conservation of linkage and evolution of developmental function within the Tbx2/3/4/5 subfamily of T-box genes: Implications for the origin of vertebrate limbs. Dev. Genes Evol. 2008, 218, 613-628. [CrossRef] [PubMed]

109. Pascual-Anaya, J.; Albuixech-Crespo, B.; Somorjai, I.M.; Carmona, R.; Oisi, Y.; Alvarez, S.; Kuratani, S.; Munoz-Chapuli, R.; Garcia-Fernandez, J. The evolutionary origins of chordate hematopoiesis and vertebrate endothelia. Dev. Biol. 2013, 375, 182-192. [CrossRef] [PubMed]

110. Minguillon, C.; Gibson-Brown, J.J.; Logan, M.P. Tbx4/5 gene duplication and the origin of vertebrate paired appendages. Proc. Nat. Acad. Sci. USA 2009, 106, 21726-21730. [CrossRef] [PubMed]

(C) 2016 by the author; licensee MDPI, Basel, Switzerland. This article is an open access article distributed under the terms and conditions of the Creative Commons Attribution (CC-BY) license (http://creativecommons.org/licenses/by/4.0/). 